\title{
MODELING THE EFFICIENCY OF THE VISUAL SEARCH OF NONPOINT STATIC OBJECTS IN MATLAB ENVIRONMENT
}

\author{
Educational \& Research Institute of Information and Diagnostic Systems, \\ National Aviation University, Kyiv, Ukraine \\ E-mail: juli_k74@ukr.net
}

\begin{abstract}
The use of the created tools using the MatLab interface to determine the visual search of nonpoint (extended) static objects on the runway, depending on the transparency of the atmosphere is proposed. The use of tools for determining the effective search for prolonged static objects at civil aviation aerodromes taking into account the boundary value of contrast adopted by the normative documents of ICAO allows to obtain of a graphic representation of dependencies: the probability of observation from meteorological conditions, the estimation of the contrast, the angular size of a static non-point object at observation from different distances, distance of visibility of aerodrome fire from meteorological conditions. The model contains a sufficient number of input parameters to minimize the time to base the decision on the visual search of non-point (extended) static objects on the runway of the civil aviation aerodrome.
\end{abstract}

Index Terms—Nonpoint objects; visual search; probability.

\section{INTRODUCTION}

Determining the effectiveness of the visual search of the prolonged static objects in complex weather conditions during approach is important. Various methods were used to solve the problem: theoretical calculations, experiments, flight checks. At present, more attention is shared to the effectiveness of the visual search using simulations with the reduction of the actual experiment. In order to reduce the financial cost, it is proposed to use simulation during evaluation of a visual image created by static nonpoint objects at civil aviation aerodromes. The probability of finding an extended static object influences on the formation of a visual picture that can be determined by simulation in the MatLab environment.

\section{OVERVIEW OF EXISTING CLASSIFICATION SYSTEMS}

Current normative documents [1] provide recommendations for the determination of the limiting values of lighting on the retina of the eye and the law of determining the visibility distance taking into account the complex meteorological conditions.

The author in [2] outlined the laws of visual observation of objects, depending on the conditions of observation and characteristics of the object itself.

\section{PRoblem Statement OF AIDED CLASSIFICATION}

The brightness mode of the extended objects of the runway significantly influences on the safety during the approach of aircraft in complex meteorological conditions, and the visual observation itself depends on the visibility distance and the clear perception of the contrast picture of the aerodrome. To set a visual contact, it is necessary to determine the contrast of the brightness of the objects on the runway at any time of day in all ranges of meteorological distance visibility.

In accordance with ICAO Doc 9328-AN / 908 "Guidance on the Practice of Tracking Visibility and Reporting of RVs" [1], visibility of markers is determined by the limit contrast sensitivity of the eye, when the object can be distinguished from the background defined by the law of Koshmider:

$$
C_{x}=C_{0} T^{x}=C_{0} e^{-\sigma x},
$$

where $C_{0}$ is the coefficient of its own brightness of the object, $T$ is transparency of the atmosphere; $\sigma$ is Absorption rate by atmosphere.

The black object has its own brightness equaled to zero, but when it is observed at a distance, it has a visible brightness caused by light scattering due to the influence of the atmosphere. Thus, its own brightness contrast is equal to one, and therefore equation (1) takes the following form:

$$
C_{x}=T^{x}=e^{-\sigma x} .
$$

When the object is removed from the observer, the object remains visible until the visible contrast $\left(C_{x}\right)$ of the brightness quantitatively equaled to $(\varepsilon)$, the threshold of contrast sensitivity of the eye therefore:

$$
\varepsilon=T^{x}=e^{-\sigma x}
$$

at a distance $(x)$. 
To privide the safety of landing and take-off of aircraft, pilot must determine the position in space with respect to the runway. As a general rule, flight safety is achieved by visual observation of the runway and approaches to it and is characterized by the term "visibility" (visibility in the atmosphere). The visibility of objects depends on many factors, the main of which is the contrast between the object and its surrounding background, weakening the light by the atmosphere and the angular size of the object. The greater the contrast of the object with the background, the more visible the object is on this background.

It is believed that the visual system gives a person up to $90 \%$ of all received information. Obtaining information about the outside world with the help of vision can always be considered as a successive or simultaneous solution of tasks. Tasks may be related to search and finding an object. Under certain conditions, the eye can not distinguich the object. In this case, it is said that the object is below the threshold of visual perception, the probability of observation is zero. Under other conditions, the eye instantly, clearly recognizes the object - in this case, the probability of observation is $100 \%$. It is clear that there is an area after which one can speak about one or another degree of probability of the visual task correct solution.

Researches carried out in a number of states in the field of the visibility of objects, have shown that the threshold of contrast sensitivity of the eye varies depending on the size of the subject. For approximately square objects with angular dimensions greater than 0.5 degrees ), the threshold of contrast sensitivity of the eye is $\varepsilon=0.02$, and ( for objects with angular dimensions less than 0.15 degrees this volue is 0.05 . Experimental results of field observations carried out with black marker plates in a wide range of visibility conditions, including fog, confirmed the validity of the Koshmider law and showed the expediency of using the threshold of contrast sensitivity of the eye, approximately equal to 0.05 . The International Civil Aviation Organization (ICAO) and the World Meteorological Organization (WMO) believe that a value of 0.05 is acceptable for visual observations. Taking into account this value the equation takes the following form:

$$
e^{-\sigma x}=0.05 \text {. }
$$

That is, the solution of the visual problem is possible in cases when the conditions of visibility exceed the threshold values of illumination on the pupil of the eye of the observer, in our case, we consider the pilot of the aircraft.
The term "visibility" of the object has a broad interpretation and is associated with meteorological conditions, in particular with atmospheric optics, light engineering, physiological optics, and others.

It is known that the visual perception of extended objects, which include markers on the artificial covering of the runway, is determined by their brightness.

The location of nonpoint objects is most often known if the placement of markers falls into some field of view. To find the object associated with its search, the contrast of the brightness of the nonpoint object with the background should be greater the threshold value equaled $\varepsilon=0.05$ and the limiting illumination on retina of the eye should be greater than $E_{\mathrm{tr}}=2 \cdot 10^{-8} \mathrm{~lx}$ at a brightness of the background equaled is $10^{-6} \mathrm{~cd} / \mathrm{m}^{2}$, and the greater the probability of its finding, the smaller the search time.

Dependence of threshold illumination $E_{\text {tr }}$ epop from the brightness of the background $L_{b}$ is a continuous function that is approximated by the expression:

$$
\log E_{\mathrm{tr}}=0.05\left(\log L_{b}\right)^{2}+0.57 \log L_{b}-6.66,
$$

where $E_{\mathrm{tr}}$ is the threshold illumination, $1 \mathrm{x} ; L_{b}$ is the brightness of the background, $\mathrm{cd} / \mathrm{m}^{2}$.

It is believed that at the stage of visual piloting, for a steady visual contact of a pilot with a nonpoint object, the brightness of the extended objects should create in the plane of the pupil of the eye the illumination which must be is not lower than the threshold. The distance to an extended object at the beginning of visual piloting depends on many factors, but the number of these values is reduced to four depending on the category of landing. The influence of the factors of of the atmosphere transparency is taken into account by the value of the specific transmittance, which varies from 0.9 to $10^{-8.5}$.

The obtained information through the view can be considered as a number of problems of search and finding an object, recognizing it by means of a number of features (form, color, presence of details, etc.), that is, visual tasks.

It is clear that there is an area for which one can speak about one or another degree of reliability of the correct solution of the visual task. For the visual search of extended objects, the main factors that determine their visibility by eye in the environment of the signal propagation (the atmosphere) is:

- contrast of the observation object with the background;

- angular dimension of view field; 
- search time; transparency of the atmosphere;

- object speed; probability of detection;

- observer adaptation state.

The presence of other objects in the field of vision, influences on the detection of an object as well. The probability of detecting extended objects is determined by the expression [2]:

$$
P=1-\exp \left(-\left(c \varepsilon^{2} \gamma^{3} L^{0.3} t\right) /(2 \beta)^{2}\right),
$$

where $P$ is probability of detection; $c$ is coefficient characterizing the individual characteristics of the observer. From the experiment for binocular vision $c=16 \mathrm{deg}^{2}\left(\mathrm{~cd} / \mathrm{m}^{2}\right)^{2} 1 \mathrm{x}^{-2} \mathrm{c}^{-1}, \varepsilon$ is contrast of brightness with respect to the background; $t$ is search time, c; $2 \beta$ is the angular size of the search field, degree; $L$ is background brightness, $\mathrm{cd} / \mathrm{m}^{2} ; n$ is a coefficient that depends on the brightness of the background and is calculated by the empirical formula:

$$
n=0.6+0.1 \cdot \lg L,
$$

within brightness changes:

$$
10^{3} \mathrm{~cd} / \mathrm{m}^{2}<L<30 \mathrm{~cd} / \mathrm{m}^{2},
$$

if $L>30 \mathrm{~cd} / \mathrm{m}^{2}$ then $n=0.75$; if $10^{-6} \mathrm{~cd} / \mathrm{m}^{2}<L<10^{-3} \mathrm{~cd} / \mathrm{m}^{2}$ then $n=0.3$.

If we set certain values of factors, then we can determine the required illumination in the plane of the pupil of the eye. Besides taking into account the law of inverse squares we may calculate the observation distance of the object on which the object will be detected with probability $P$.

\section{Proposed Algorithm of Aided CLASSIFICATION OF GROUND OBJECTS}

Using the MatLab interface, tools were created to determine the effective search for extended static objects on the runway, depending on the transparency of the atmosphere (Fig. 1). Using the developed tool with such input parameters:

- length and width of the extended static object;

- the brightness of the object and the brightness of the background on which the object is considered;

- parameters of the object's fixation by observer's, namely: angle of view sield of the observer, distance from the object to the eye of the pilot, observation time;

- data of Meteorological range of visibility.

When entering the input parameters, the model of an effective object search provides a graphical representation of the dependencies of each parameter individually:

- probability of observation from meteorological conditions;

- contrast estimation;

- angular size of static nonpoint object at observation from different distances;

- the range of visibility of aerodrome fire from meteorological conditions.

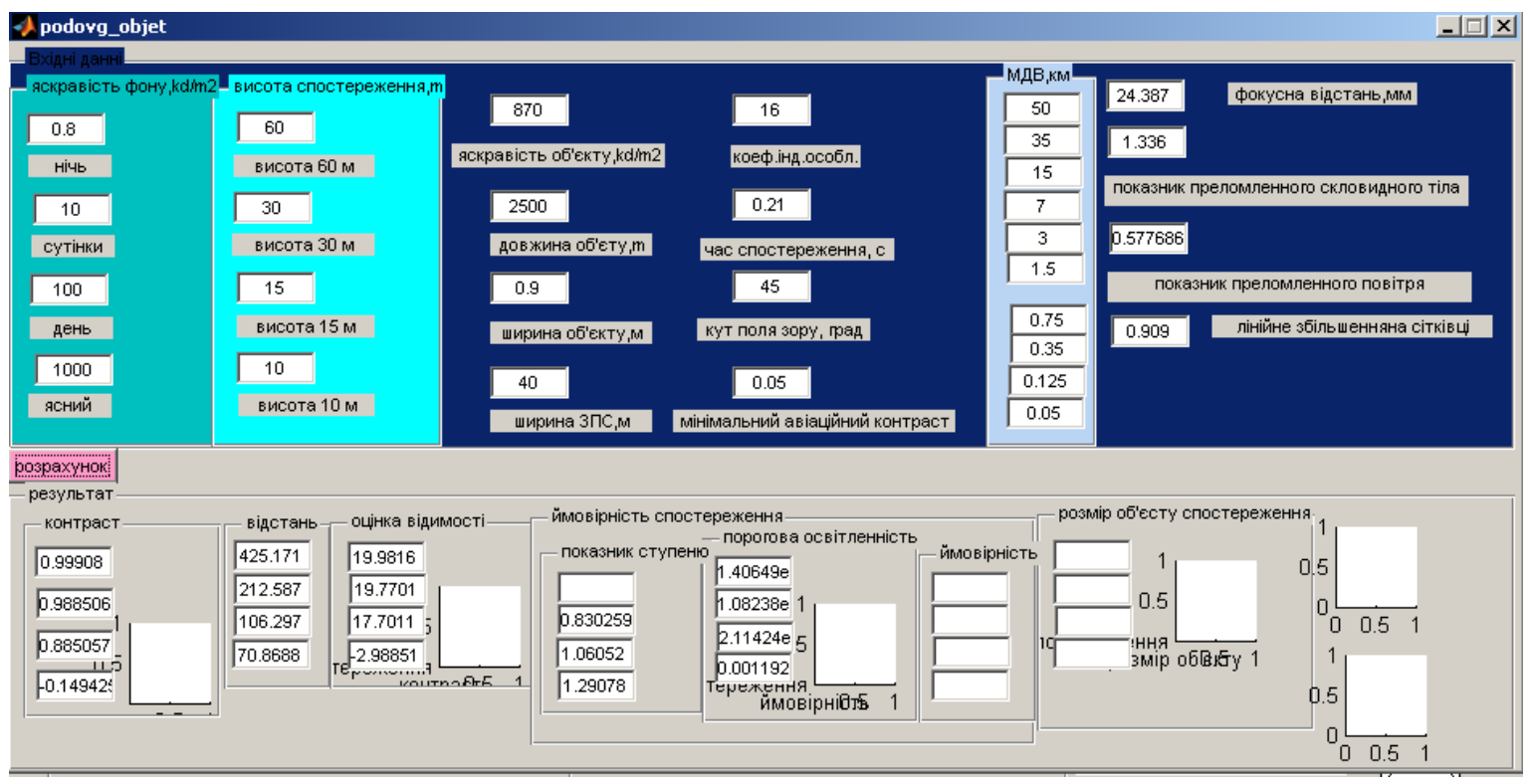

Fig. 1. Graphical interface of MatLab environment for effective visual search of nonpoint static objects and providing estimation of element's visibility on the runway

\section{CONCLUSIONS}

Use of the created tool in the MatLab environment for the visual search of nonpoint objects on the runway, taking into account the meteorological range of visibility, allows to reduces the time to determine the suitability of elements on the surface of the runway, depending on the conditions of observation, at the same time, it is possible to assess the visibility 
of nonpoint object, as well as determine the probability of observing an extended static object, which will help justify their use in runways of civil aviation aerodromes.

\section{REFERENCES}

[1] ICAO Doc 9328-AN / 908 "Guide on the Practice of Tracking and Tracking Visibility on Runway Tracking" 3rd ed., ICAO, 2005, 124 p.

[2] N. P. Travnikova, Effectiveness of visual search, Moscow: Mechanical Engineering, 1985, 128 p.
[3] V. Kondrashov, and S. Korolyov, MathLab as a system of programming of scientific and technical calculations, Moscow: Mir, Institute of Strategic Stability of the Ministry of Atomic Energy of the Russian Federation, 2002.

[4] I. B. Badriev, V. V. Banderov, and O. A. Zadvornov, Develop a graphical user interface in the MathLab environment, Tutorial, Kazan: Kazan State University, 2010, 113 p.

Received April 23, 2018

Yuliia Kvach. Candidate of Science (Engineering). Associate Professor.

Department of Computerized Electrical Systems and Technologies, Educational \& Research Institute of Information and Diagnostic Systems, National Aviation University, Kyiv, Ukraine.

Education: National Aviation University, Kyiv, Ukraine, (2004).

Research area: Mathematical modeling and monitoring of visual aids.

Publications: more than 40 papers.

E-mail: juli_k74@ukr.net

Ю. М. Квач. Моделювання ефективності візуального пошуку неточкових статичних об'єктів в середовищі MatLab

Запропоновано використання створеного інструментарію з використанням інтерфейсу MatLab для визначення візуального пошуку неточкових (подовжених) статичних об'єктів на злітно-посадковій смузі в залежності від прозорості атмосфери. Використання інструментарію по визначенню ефективного пошуку подовжених статичних об’єктів на аеродромах цивільної авіації виходячи з граничного значення контрасту, що прийнято нормативними документами ICAO дозволяє виведення графічного зображення залежностей: імовірність спостереження від метеорологічних умов, оцінку контрастності, кутовий розмір статичного неточкового об'єкту при спостереженні з різних відстаней, дальність видимості аеродромного вогню від метеорологічних умов. Модель містить достатню кількість вхідних параметрів, що дозволяє мінімізувати час на обгрунтування прийняття рішення щодо візуального пошуку не точкових статичних об'єктів на злітно-посадковій смузі аеродрому цивільної авіації.

Ключові слова: неточкові об’єкти; візуальний пошук; ймовірність спостереження.

Квач Юлія Миколаївна. Кандидат технічних наук. Доцент.

Кафедра комп’ютеризованих електротехнічних систем та технологій, Навчально-науковий інститут інформаційно-діагностичних систем, Національний авіаційний університет, Київ, Україна.

Освіта: Національний авіаційний університет, Київ, Україна, (2004).

Напрям наукової діяльності: математичне моделювання і моніторинг візуальних засобів.

Кількість публікацій: понад 40.

E-mail: juli_k74@ukr.net

Ю. Н. Квач. Моделирование эффективности визуального поиска неточечных статических объектов в среде MatLab

Предложено использование созданного инструментария с использованием интерфейса MatLab для определения визуального поиска неточечных (продолговатых) статических объектов на взлетно-посадочной полосе в зависимости от прозрачности атмосферы. Использование инструментария по определению эффективного поиска продолговатых статических объектов на аэродромах гражданской авиации исходя из предельного значения контраста, принятого нормативными документами ИКАО позволяет демонстрировать графические изображения зависимостей: вероятность наблюдения от метеорологических условий, оценку контрастности, угловой размер статического неточечный объекта при наблюдении с различных расстояний, дальность видимости аэродромного огня от метеорологических условий. Модель содержит достаточное количество входных параметров, позволяет минимизировать время на обоснование принятия решения о визуальном поиске неточечных статических объектов на взлетно-посадочной полосе аэродрома гражданской авиации.

Ключевые слова: неточечные объекты; визуальный поиск; вероятность наблюдения.

Квач Юлия Николаевна. Кандидат технических наук. Доцент.

Кафедра компьютеризованных электротехнических систем и технологий Учебно-научный институт информационно-диагностических систем, Национальный авиационный университет, Киев, Украина.

Образование: Национальный авиационный университет, Киев, Украина, (2004).

Направление научной деятельности: математическое моделирование и мониторинг визуальных средств.

Количество публикаций: более 40.

E-mail: juli_k74@ukr.net 